en "Poetries International", die naguil-op'n-kluit wat sy habitat moet verlaat om 'n ster van "pens-en-pootjiesblaaie" te word (201), die pelgrim van die kuberruimte, ewewigsoekend in ' $\mathrm{n}$ wêreld van kitsverandering.

So word die vervlietende moment, die flits-insig op verganklike koerantpapier, die onvoltooide gesprek, ten slotte tog bestendig, en kan Die stilte ná die boek'n verwysingspunt word in die geskiedenis van die Afrikaanse literêre sisteem in die oorgangstye van die millenniumwending. Daarmee neem Etienne van Heerden sy plek naas sy groot voorgangers in die literêre joernalistiek met onderskeiding in.

Elize Botha

Emeritus professor

Universiteit van Suid-Afrika

\section{Power and Terror - Post-9/11 Talks and Interviews. Noam Chomsky. J. Junker- man \& T. Masakazu (eds.).}

Houghton: Jacana. 2003. 156 pp. ISBN 1 919931-59-7.

In 2002, 'n paar maande na die gewraakte terreuraanvalle van September 2001 in die VSA het'n Japanese filmmaatskappy'n dokumentêr, Power and Terror: Noam Chomsky in Our Times, vervaardig en die boek wat hier geresenseer word, is 'n uitvloeisel van die filmprojek. Die boek bestaan uit vier afdelings: 'n onderhoud vir die rolprent met Chomsky - sy siening van die terreuraanvalle, die daaropvolgende oorlog in Afganistan en die rol van Japan in die oorlog, 'n toespraak van Chomsky, "US arms, human rights and social health", 'n aantal gesprekke met hom, hoofsaaklik gebaseer op toesprake van hom en die bespreking wat dit ontlok het wanneer die gehoor vrae kon vra en laastens 'n afdeling met algemene inligting oor die skrywer en 'n lys van publikasies van hom wat spesifiek betrekking het op van die vraagstukke wat in hierdie boek gedek word. Die deurlopende tema is die mate waarin Amerika self skuldig is aan ' $\mathrm{n}$ vorm van staatsterreur in sy buitelandse optrede en dat indien die Amerikaners dit halt sal roep, dit onmiddellik' $n$ reuse verskil sal maak in die voorkoms van terreur wêreldwyd. 'n Sub-tema is die rol van intellektuele (sien veral 15-20) - hulle stilswye of selfs verdediging van en ondersteuning vir die Amerikaanse posisie, omdat as terreur op eie bodem plaasvind, dit moeilik word om enigsins objektief te kyk na die oorsaak daarvan en om regeringsbeleid te bevraagteken.

'n Paar aspekte rondom die publikasie val dadelik op. Dit is 'n boek gemik op die leek en dien as eenvoudige inleiding tot Chomsky se politieke geskrifte en opinies - dit is nie 'n boek vir die intellektueel of die vakspesialis of mense wat werklik pitkos soek wanneer hulle oor die groot vrae van die dag wonder en daarmee worstel nie. Dit is nie die akademikus Chomsky waarmee' $n$ mens hier te doen het nie, maar 'n Chomsky in gesprek met gewone mense wat ernstige vrae vra oor die rol van die VSA in die kontemporêre internasionale politiek. Daarmee maak ek nie die publikasie af as minderwaardig nie - inteendeel. Chomsky praat nie neerhalend of "af" na sy vraestellers nie, maar hanteer vrae en opmerkings met begrip en respek en probeer eerlike antwoorde verskaf. Vir akademici kan hierdie juis goeie leesstof wees, want Chomsky word 'n rolmodel wat wys wat die taak van die intellektueel in die openbare lewe is.

Maar dit gaan nie noodwendig dieper insig bring in die vrae wat aangespreek word nie. Daarvoor moet 'n mens teruggan na die skrywer se akademiese werk, en 'n uitstekende voorbeeld hiervan, minstens 
binne die dissipline Internasionale Verhoudinge, is byvoorbeeld sy "Moral truisms, empirical evidence and foreign policy" wat in Oktober 2003 in die gesaghebbende Britse joernaal, Review of International Studies, verskyn het.

Chomsky is nou reeds dekades lank bekend as iemand wat onverskrokke standpunt inneem, gewoonlik teenoor Amerikaanse buitelandse beleidsoptredes, en wat meedoënloos "sy land" se buitelandse optredes onder die vergrootglas plaas en dan veral teenoor die skynheiligheid van Amerikaanse optrede kritiek uitspreek. Vir talle mense is hy die toonbeeld van wat met die word "patriot" bedoel word, in teenstelling met "nasionalis". Onderliggend aan sy werk is die idee dat die VSA ' $n$ staat is waarin groot individuele vryheid bestaan, ' $n$ land wat die potensiaal het om deur sy buitelandse beleid 'n daadwerklike bydrae te maak tot internasionale vrede, sekuriteit en veral geregtigheid, maar dat die verskillende administrasies, hetsy Demokraties of Republikeins (hy is net so krities teenoor die Clinton-administrasie as teenoor die huidige Bush-administrasie), vanweë elitebelange, hierdie potensiaal nooit verwesenlik nie. Sy siening herinner sterk aan dié van die neo-Marxis, Ralph Miliband, dat die (kapitalisitiese) staat uiteindelik die agent van die heersende klas is - die rykes en bevoorregtes in die samelewing: "The media are huge corporations that share the interests of the corporate sector that dominates the government" (98).

Chomsky se kritiek op die VSA se buitelandse beleid, veral in die mate waarin Amerikaanse optrede neerkom op direkte deelname aan terreur (staatsterreur), word vir hom van oorwegende en oorheersende belang. Dit is te verstane. En terloops, 'n mens is geneig om te vergeet, en Chomsky herinner die leser hieraan, dat die sogenaamde "war on terror" (of soos sommiges van ons daarna begin verwys, die "war of terror") reeds uit die Reagan-era dateer toe dit die fokuspunt van Amerikaanse buitelandse beleid geword het. Sy ontleding van die VSA se optrede in en teen verskeie state in Sentraal-Amerika (spesifiek Nicaragua), teen die Palestyne en in Viëtnam gedurende die sestigerjare (afdeling twee van die boek) toon 'n Amerika wat lank reeds, in Chomsky se woorde, slegs begaan is oor eiebelang (lees: korporatiewe of elitebelang, 'n ou probleem in die ontleding van internasionale politiek - wie is die staat? Is dit werklik 'n "unitary actor"?): "But they [slagoffers van geweld en terreur buite die VSA] can be any colour, any religion, it doesn't really matter. The principle is: does it affect US interests?" (106).

Vir'n Afrika-leser raak hierdie standpunt hinderlik wanneer Chomsky tydens 'n vraesessie na 'n toespraak gekonfronteer word met ' $n$ aanhaling van generaal Romeo Dallaire, die Kanadese offisier wat tydens die Rwandese menseslagting van 1994 aan die hoof van die VN vredesmag gestaan het. Dallaire het gesê (dit word in die teks geparafraseer): "Rwanda was too small, too poor and too black for anyone to care." Chomsky gee toe dat daar waarheid in mag steek, maar sy (bykans) obsessie bly by die VSA en dié se direkte betrokkenheid by terreur en geweld. Die VSA se rol in multilaterale organisasies, byvoorbeeld die Verenigde Nasies, waar besluite oor intervensie in die geval van menseslagtings gemaak word, is vir hom nie van direkte belang nie: "He's [Dallaire] talking about something bad, namely our unwillingness to do anything to stop atrocities. But much worse than that, incomparably worse, is our willingness to participate in atrocities".

Hierdie resensent deel die mening van talle ander dat die internasionale gemeenskap, en spesifiek die VSA as permanente lid van die Veiligheidsraad, net so skuldig 
was aan die Rwandese slagting as dié wat dit uitgevoer het. Nietemin, 'n mens kan die publikasie aanbeveel, veral vir mense wat 'n oorhoofse indruk wil kry van die omvang van Chomsky se politieke oeuvre. Omvattende hantering van vraagstukke gaan die leser nie hier kry nie en dit is nie moontlik om uit hierdie versameling naastenby die omvang en diepte van die man se empiriese navorsing en interpretasie daarvan te peil nie. Maar wat Chomsky deurentyd, ook in dié publikasie, demonstreer, is die aard van die werklike kritikus: die persoon of kundige of denker wat na beide kante van ' $n$ saak kan kyk en in beide gevalle kritiek kan uitspreek, nie partisaans en eensydig net een party afkraak nie.

Sy sterk afkeur is nie net teen die VSA gemik nie (hoewel hy die oorwig van skuld voor die Amerikaners se deur plaas wanneer dit by terreur kom - immers het die kleiner en swakker partye bittermin wapens om mee te baklei), maar ook teen alle ander terreurgroepe. In die VSA word hy en ander kritici van die oorlog teen terreur as onpatrioties uitgekryt en in sommige gevalle verloor akademici tans selfs sekere voorregte en regte (byvoorbeeld navorsingstoekennings) wanneer hulle te openlik Amerikaanse optrede kritiseer. Van hulle, en spesifiek Chomsky, word ook op 'n ander manier gestraf - hulle werk word grootliks geïgnoreer en afgemaak as te "polemies" - 'n swaar straf vir akademici wat juis daarop uit is om in gesprek te tree met ander.

Nietemin bly Chomsky getrou aan 'n kultuur van kritiese ingesteldheid en bly hy grootliks 'n optimis: mense kan deur aktivisme die wêreld verander, en sy taak, goed vergestalt in hierdie publikasie, is om mense van die nodige feite en ontleding te voorsien sodat hulle op ' $n$ ingeligte manier aktivisties kan optree.

Maxi Schoeman

Universiteit van Pretoria 